
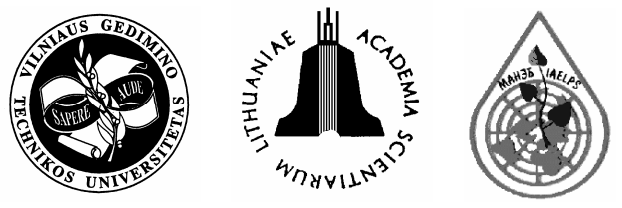

\title{
APPLICATION OF BACKWARD AIR MASS TRAJECTORY ANALYSIS IN EVALUATING AIRBORNE POLLEN DISPERSION
}

\author{
Ingrida Šaulienė, Laura Veriankaitė \\ Dept of Environmental Sciences, Šiauliai University, \\ Vilniaus g.88, LT-76285 Šiauliai, Lithuania.E-mail: oikos@fm.su.lt \\ Submitted 30 Mar 2006; accepted 15 Apr 2006
}

\begin{abstract}
To investigate airborne pollen movement aerobiologists use backward air mass trajectories. In the present paper the peculiarities of airborne birch pollen dispersion are analysed. In 2005 at Šiauliai Aerobiology Station pollen was recorded using Hirst-type spore trap. The situation of birch bloom in neighbouring European countries was evaluated according to the European Aeroallergen Network database. It was generalized and used to prove long-range pollen transport. Air mass trajectories were calculated according to the HYSPLIT 4 model the trajectory drawing principle of which is based on the integration of the position of air mass with regard to time. The present study has shown that backward air mass trajectory analysis may be applied in investigating relationship among pollen dispersion, meteorological conditions and air mass transport. It is estimated that at Šiauliai Aerobiology Station the dynamics of pollen concentration is determinated by local flora and airborne pollen long-range transport. The evaluation of pollen dispersion by the backward air mass trajectory method presented in the paper established precondition to look for possibilities of application of the HYSPLIT 4 model to prepare the forecasts of pollen dispersion.
\end{abstract}

Keywords: pollen, meteorological conditions, long-range transport, backward air mass trajectories, birch pollination, air pollution.

\section{Introduction}

Investigaions into the dynamics of airborne birch (Betula L.) pollen are performed in many European states [1-4]. The attention of aerobiologists, botanists, planters, clinicists to this biological kind of air pollution has appeared because of large amounts of pollen dispersed during bloom period and decreasing life quality of the part of human population. It has been estimated that most often in spring the allergy caused by birch pollen is diagnosed [5]. Using special methods, it has been shown that people are sensitive even to small amounts of pollen: people experience unpleasant sensations when the number of birch pollen in 24 hours reaches 35 grains $/ \mathrm{m}^{3}$, for people ill in asthma the process of illness becomes more complicated when $68-81$ grains $/ \mathrm{m}^{3}$ is recorded, 81-252 grains $/ \mathrm{m}^{3}$ causes conjunctivitis and/or rhinitis [6]. The periods of birch pollination at different aerobiology stations in Lithuania were evaluated [7], but the influence of longrange transport on pollen dynamics was not shown.

Airborne pollen dispersion may be forecast having evaluated biological features of a plant, climate factors and circulation of the atmosphere. The situation analysis becomes more complicated because of the lack of unanimous opinion on birch reproduction cycle. In some authors' opinion, the triennial rhythm is characteristic of birch [8] maintaining synchrony above large territories; in other authors' opinion, the rhythm is biennial (Spieksma et al., 2003). For the forecasts, it is not less important to identify the beginning of bloom of the plant that is changing year after year and is partially determined by meteorological factors in the period of blossom formation [5].

Performing the forecast, the necessary evaluation of interaction between airborne pollen concentration and environmental factors is conducted [9]. It is shown that warm and wet weather influences bigger airborne birch pollen concentrations [2], and comparing pollen dynamics with temperature (minimum and/or maximum) strong positive correlation is observed, while comparing it with rainfall negative correlation occurs [4]. It has been estimated that airborne birch pollen concentration significantly increases when anticyclone is dominating, relative humidity falls below $70 \%$, and the temperature reaches $6-11{ }^{\circ} \mathrm{C}$ [6]. Thus, meteorological conditions and weather types have a vital influence not only on pollen formation, but also on the release of pollen from anthers and airborne concentration.

To investigate the movement of airborne pollen aerobiologists use backward air mass trajectories [9]. Using this method, long-range transport and the movement of airborne pollen is investigated.

The aim of the present study is to establish relationship of pollen dispersion, meteorological conditions and air mass transport using a selected case for modeling. Such a study helps to forecast probability for pollen of a nonlocal origin to get to the territory of Lithuania and the dynamics of biological pollution in the atmosphere. 


\section{Materials and methods}

\subsection{Object}

Birch forests in the whole Šiauliai region cover about $29 \%$ (61 300 ha) of the forest area and make up $15 \%$ of the Lithuanian territory [10]. In Šiauliai city surroundings birch is in the second place according to number and makes up about $32 \%$ of the forest area.

For the case study, data about the amount of airborne birch pollen are obtained from Šiauliai Aerobiological Station. Pollen was recorded using the Hirst-type spore trap raised $18 \mathrm{~m}$ above the ground and localized in the western part of the city $\left(55^{\circ} 56^{\prime} 96 \mathrm{~N}, 23^{\circ} 16^{\prime} 95 \mathrm{E}\right)$. Samples were prepared, and the data were processed according to a standard method [11]. Birch pollen counts were recorded every 2 hours and expressed as the number of grains counted per transect (field of view of $0,55 \mathrm{~mm}$ diameter). Each transect represented $0,001 \%$ of the total volume of sampled air.

The situation of birch bloom in May in neighbouring European countries was evaluated referring to the European Aeroallergen Network (EAN) database. It was generalized and used to prove long-range pollen transport with the help of air mass.

\subsection{Meteorological data}

The meteorological data for Šiauliai city were provided by Šiauliai Meteorological Station of Hydrometeorological Service of Lithuania at the Ministry of Environment. The station is in the eastern part of the city about $3 \mathrm{~km}$ from Šiauliai Aerobiological Station.

\subsection{Backward trajectory analysis}

Air mass trajectories were calculated according to HYSPLIT 4 model [12] the trajectory drawing principle of which is based on the integration of the position of air mass with regard to time. Since air mass is transported with the help of the wind, its passive transport may be calculated evaluating three-dimensional means of speed vector when the particles are in the primary position $P(t)$ and the first approximate position $P^{\prime}(t+d t)$. Speed vectors are interpolated with regard both to space and time. Using the HYSPLIT 4 model the first approximate position is calculated:

$$
P^{\prime}(t+d t)=P(t)+V(P, t) d t .
$$

While the last position of air particles:

$$
P(t+d t)=P(t)+0,5\left[V(P, t)+V\left(P^{\prime}, t+d t\right)\right] d t .
$$

Thus, backward air mass trajectories may be integrated and presented graphically.

Backward air mass trajectories were calculated for every day analysed (at midnight, at 6 a.m., at noon, at 6 p.m. according to local time) at three different heights: $1500 \mathrm{~m}, 1000 \mathrm{~m}, 500 \mathrm{~m}$. The following heights were chosen because to identify air mass trajectories it is recommended to choose heights with the pressure interval of 950-10 mb. It is suggested that the use of pressures less than $950 \mathrm{mb}$ often results in parcels going into the ground [9].
With the help of the HYSPLIT 4 model the rainfall in the way of air masses was evaluated, the data were taken from the National Weather Service's NCEP (the National Weather Service's National Centers for Environmental Prediction) database.

\section{Results}

\subsection{Blooming season of birch genus (Betula L.) in Šiauliai city in 2005}

The blooming season of the plants of birch genus in 2005 lasted for 27 calendar days. During these days 5 concentration peaks dangerous to human health were recorded: May 3(397 grains $\left./ \mathrm{m}^{3}\right)$, May 6 (212 grains $\left./ \mathrm{m}^{3}\right)$, May 8 (205 grains/m³), May 13-15 (560-286 grains $\left./ \mathrm{m}^{3}\right)$ and May 21 (347 grains/m³) (Fig 1).

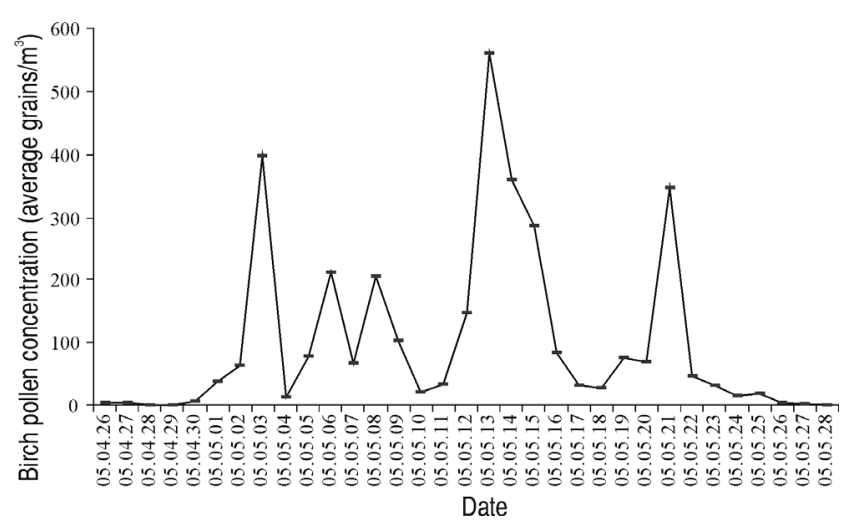

Fig 1. Birch pollen season in Šiauliai in 2005

Having evaluated the meteorological situation during the period of birch pollination it was identified that conditions to release pollen from anthers were sufficient: relative humidity during the season fluctuated from 53$88 \%$, average weather temperature in 24 hours was from $7,5-20,5^{\circ} \mathrm{C}$, average wind speed in 24 hours reached $1,4-4,8 \mathrm{~m} / \mathrm{s}$, the sunniness was changing at an interval of $1,3-15,2$ hours, the rainfall was $0,6-11,6 \mathrm{~mm}$.

The study of airborne pollen dynamics was conducted choosing 3 days the peaks of which were the most distinct during the entire period of birch pollination: on 3 , 13 and 21 May (Fig 2).

On 3 and 21 May at Šiauliai Aerobiological Station peaks of pollen concentration atypical of morning hours were recorded. On May 13 it was the middle of pollination season, but abundant rainfall produced atypical conditions for pollen dispersion. Having established presumption about the dispersion of pollen of a nonlocal origin, backward air mass trajectory analysis to perform the case evaluation was used.

\subsection{Pollen dispersion and backward air mass trajectory analysis on 3 May 2005}

During 24 hours of analysis the pollen peak was recorded at night hours (Fig 2). Having evaluated pollen recorded during 24 hours it was estimated that $67 \%$ of the total amount was recorded from midnight to 6 a.m.). 


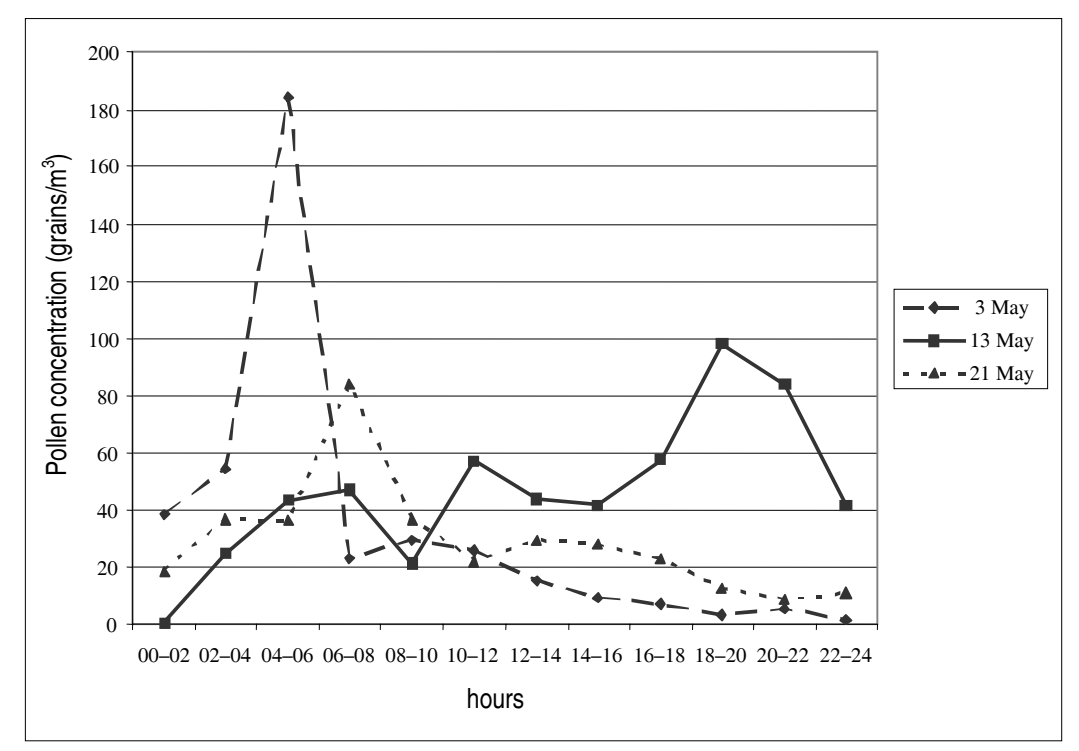

Fig 2. Birch pollination on 3, 13 and 21 May

The biggest pollen concentration that day was from 4 a.m. to 6 a.m. $\left(184,11\right.$ grains $\left./ \mathrm{m}^{3}\right)$ and significantly decreased in the afternoon hours. The meteorological situation of 24 hours was unfavourable for pollen dispersion (Table 1). An average temperature reached $8,8^{\circ} \mathrm{C}$, the rainfall (from 5:28 to 11:06) was to $1,1 \mathrm{~mm}$, the day was cloudy, the variable wind speed reached $2,8 \mathrm{~m} / \mathrm{s}$. Knowing that for the release of pollen from anthers a dry and sunny weather is essential, the problem of the situation analysis occurs. To evaluate the changes of pollen concentration of that day, analysis of air mass transport was conducted (Figs 3-6).

Using the HYSPLIT 4 model and the EAN database it was revealed that on 2 May very small amounts of birch pollen were recorded in Latvia, and air mass crossed this region during night hours, therefore, it could not bring pollen from this European region. Having evaluated that maximum pollen concentrations were recorded from midnight to 6 a.m. and on a bigger part of the day on May 2 local air mass was dominating, therefore, increased amounts of pollen were related to blooming of local plants in the central and southern parts of Lithuania. During later hours of May 3 little amounts of airborne pollen recorded may be related to an unfavourable meteorological situation in Šiauliai city (a high relative humidity, rainfall, a low pressure) preventing to spread pollen and an unfavourable air mass circulation because at the afternoon hours air mass came from the central and northern parts of Europe. Although, according to the EAN data, in Denmark and Poland much pollen was recorded these days, however, having evaluated meteorological conditions with the help of the model, it is possible to establish presumption that pollen may have been washed by rainfall that occurred in the way of air mass.

\subsection{Pollen dispersion and backward air mass trajectory analysis on 13 May 2005}

The 24 hours analysed were distinguished by an abundant rainfall that began at night and was gradually decreasing towards the end of the day. The total rainfall amount reached $11,6 \mathrm{~mm}$, its biggest part fell until 11 a.m. Other meteorological conditions (Table 2) were unfavourable for the release of pollen, but airborne pollen concentration under such conditions reached a maximum of the entire season (560 grains $/ \mathrm{m}^{3}$ ). Local pollen (of plants from Šiauliai surroundings) was wet and heavy and could not spread, so it was possible to establish presumption that the part of pollen could be brought together with air mass (Figs 7-10) from neighbouring regions. Having evaluated plant pollination in Europe (according to the EAN database) it was estimated that in Latvia and in the southern part of Finland big amounts of birch pollen were recorded, while in the southern and central parts of Finland birch bloom was over. The HYSPLIT 4 model showed that on May 13 air mass came from the northern part of Europe: $500 \mathrm{~m}$ above the ground air mass retained similar direction during 24 hours, while at a height of $1000 \mathrm{~m}$ and $1500 \mathrm{~m}$ it went from the North East to the North where exceptionally large amounts of birch pollen were recorded. A part of pollen could have settled together with rainfall (especially in morning hours), and the evening pollen peak occurred due to dried and airborne spread local pollen (Fig 2). The situation analysis allows to establish presumption that at Šiauliai Aerobiological Station pollen concentration in the morning of May 13 increased due to long-range transport of particles, and in the evening - due to the emission from the local flora.

\subsection{Pollen dispersion and backward air mass trajectory analysis on 21 May 2005}

On 21 May 2005 the peak of birch pollen concentration (Fig 1), recorded at Śiauliai Aerobiological Station was evaluated as noncharacteristic of the period because at the end of pollination season such an emission from local flora was impossible. The analysis of the aerobiological preparations of the 24 hours analysed (Fig 2) highlighted the pollen peak of 6 a.m. -8 a.m. showing probability of pollen of a nonlocal origin. Analysis of backward 
Table 1. Meteorological data recorded on May 3, 2005

\begin{tabular}{c|c|c|c|c|c|c}
\hline Time & $\begin{array}{c}\text { Surface level } \\
\text { pressure } \\
\mathrm{mb}\end{array}$ & $\begin{array}{c}\text { Average tem- } \\
\text { perature, } \\
{ }^{\circ} \mathrm{C}\end{array}$ & $\begin{array}{c}\text { Minimal tem- } \\
\text { perature, } \\
{ }^{\circ} \mathrm{C}\end{array}$ & $\begin{array}{c}\text { Wind speed, } \\
\mathrm{m} / \mathrm{s}\end{array}$ & $\begin{array}{c}\text { Wind direc- } \\
\text { tion, } \\
\text { degrees }\end{array}$ & $\begin{array}{c}\text { Relative } \\
\text { humidity, } \\
\%\end{array}$ \\
\hline 24 & 1006,6 & 8,5 & 8,4 & 2 & 20 & 62 \\
\hline 6 & 1004,0 & 9 & 8,2 & 3 & 180 & 71 \\
\hline 12 & 999,6 & 7,9 & 7,7 & 3 & 160 & 82 \\
\hline 18 & 997,7 & 8,7 & 8,6 & 3 & 180 & 92 \\
\hline
\end{tabular}

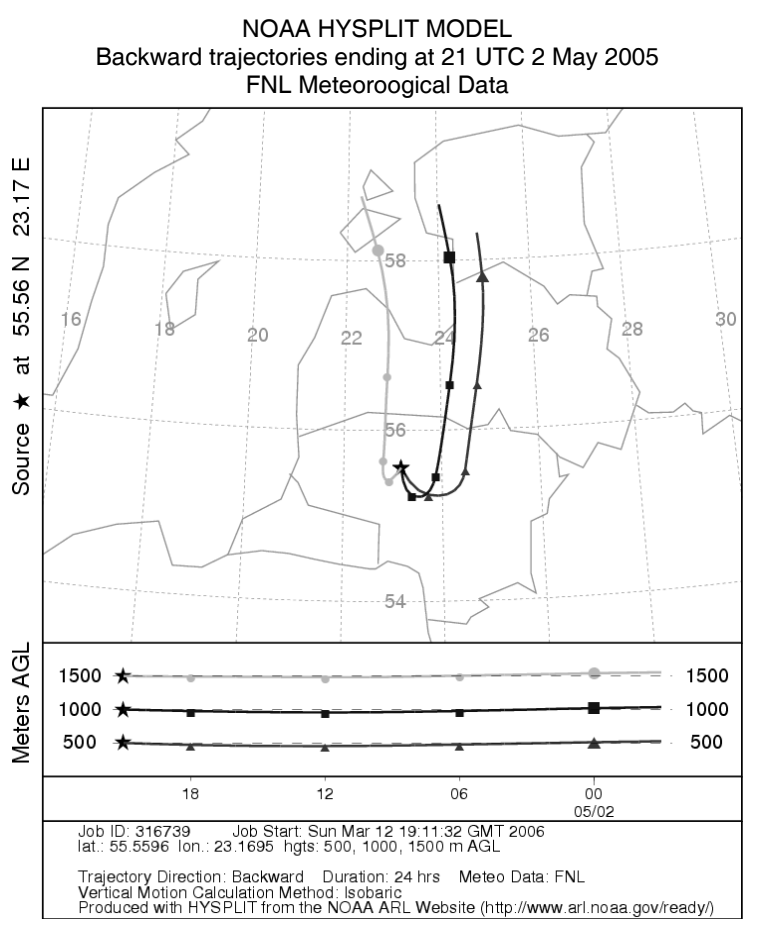

Fig 3. Backward trajectory analysis ( 24 hours) at three altitudes, start of run at 00:00, May 3, 2005

NOAA HYSPLIT MODEL

Backward trajectories ending at 3 UTC 3 May 2005

FNL Meteoroogical Data

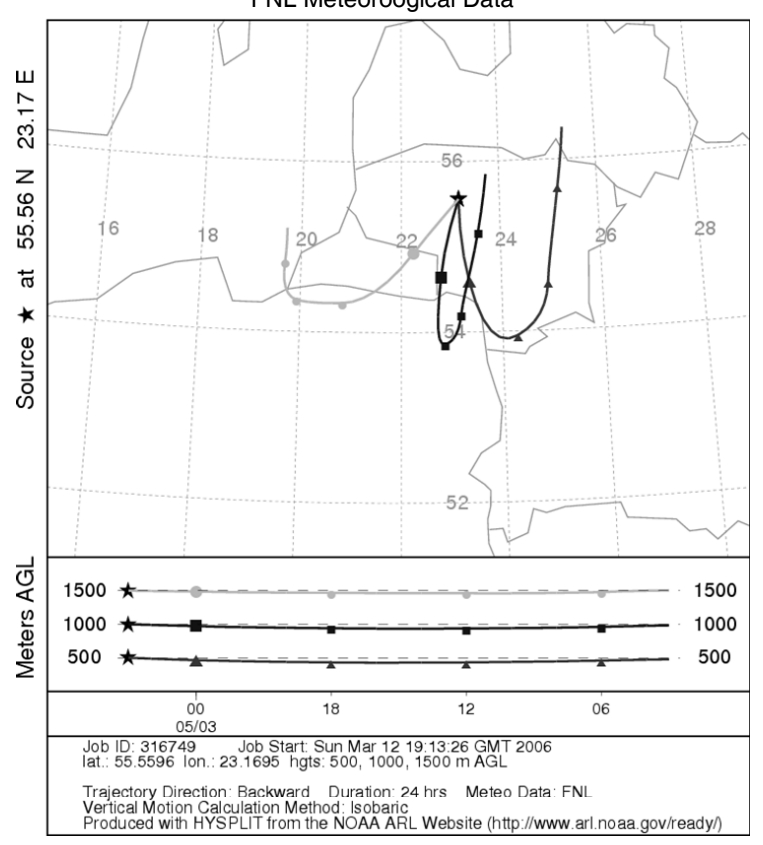

Fig 4. Backward trajectory analysis (24 hours) at three altitudes, start of run at 6:00, May 3, 2005

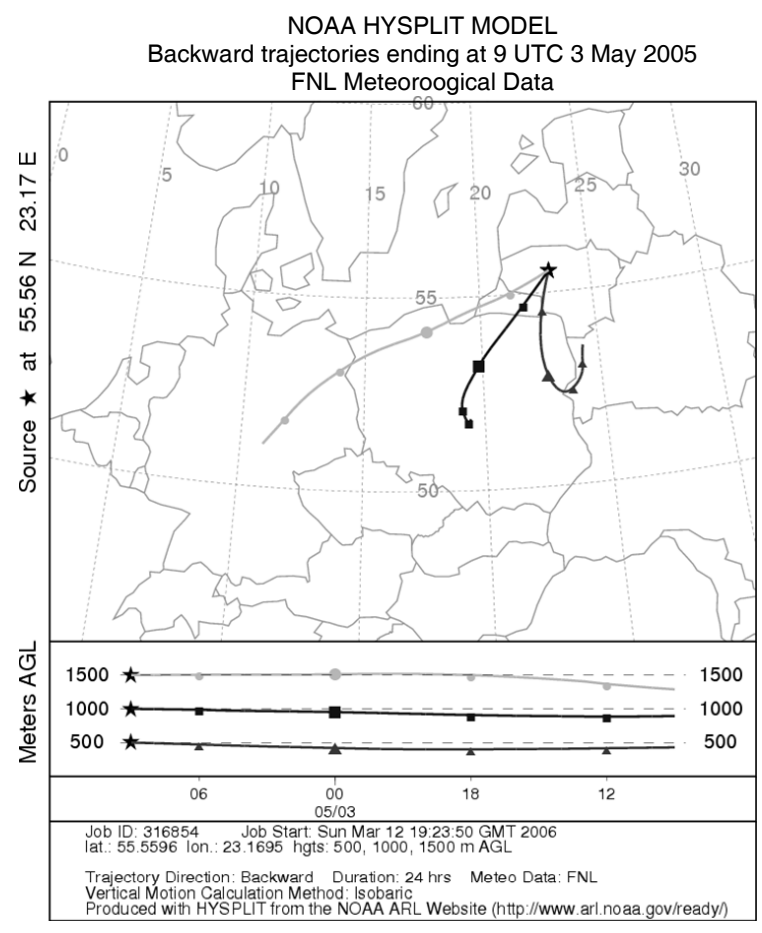

Fig 5. Backward trajectory analysis ( 24 hours) at three altitudes, start of run at 12:00, May 3, 2005

NOAA HYSPLIT MODEL

Backward trajectories ending at 15 UTC 3 May 2005 FNL Meteoroogical Data

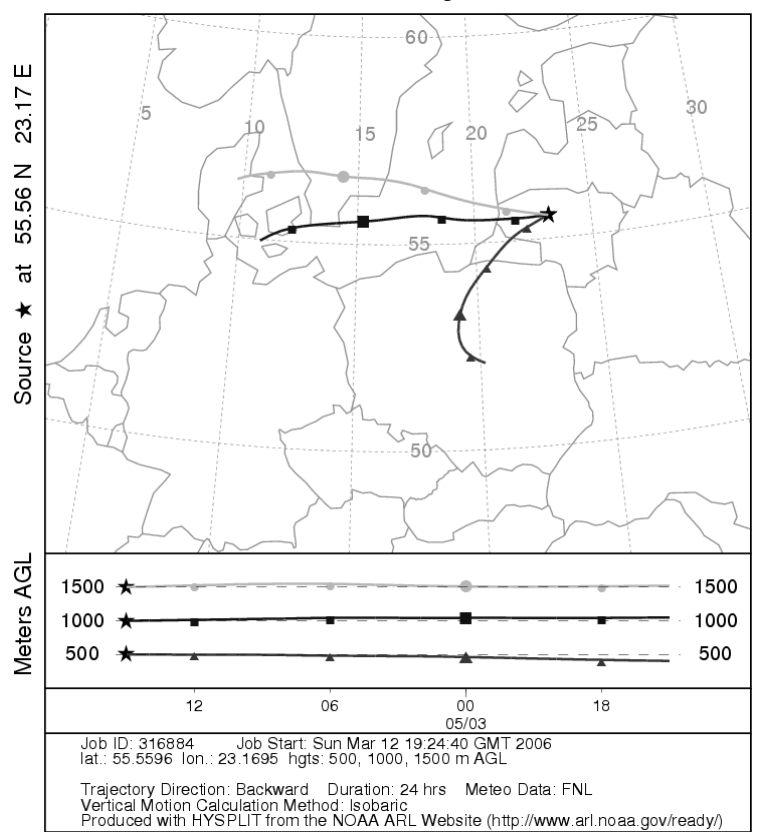

Fig 6. Backward trajectory analysis ( 24 hours) at three altitudes, start of run 18:00 hours, May 3, 2005 
Table 2. Meteorological data recorded on May 13, 2005

\begin{tabular}{c|c|c|c|c|c|c}
\hline Time & $\begin{array}{c}\text { Surface level pressure } \\
\mathrm{mb}\end{array}$ & $\begin{array}{c}\text { Average } \\
\text { temperature, } \\
{ }^{\circ} \mathrm{C}\end{array}$ & $\begin{array}{c}\text { Minimal } \\
\text { temperature, } \\
{ }^{\circ} \mathrm{C}\end{array}$ & $\begin{array}{c}\text { Wind speed, } \\
\mathrm{m} / \mathrm{s}\end{array}$ & $\begin{array}{c}\text { Wind direc- } \\
\text { tion, } \\
\text { degrees }\end{array}$ & $\begin{array}{c}\text { Relative } \\
\text { humidity, } \\
\%\end{array}$ \\
\hline 24 & 1002,4 & 6,4 & 5,9 & 5 & 360 & 91 \\
\hline 6 & 1000,0 & 6,8 & 6,1 & 5 & 360 & 93 \\
\hline 12 & 1000,5 & 10,5 & 7,9 & 6 & 340 & 64 \\
\hline 18 & 1001,6 & 12,9 & 11,4 & 5 & 340 & 55 \\
\hline
\end{tabular}

NOAA HYSPLIT MODEL Backward trajectories ending at 21 UTC 12 May 2005 FNL Meteoroogical Data

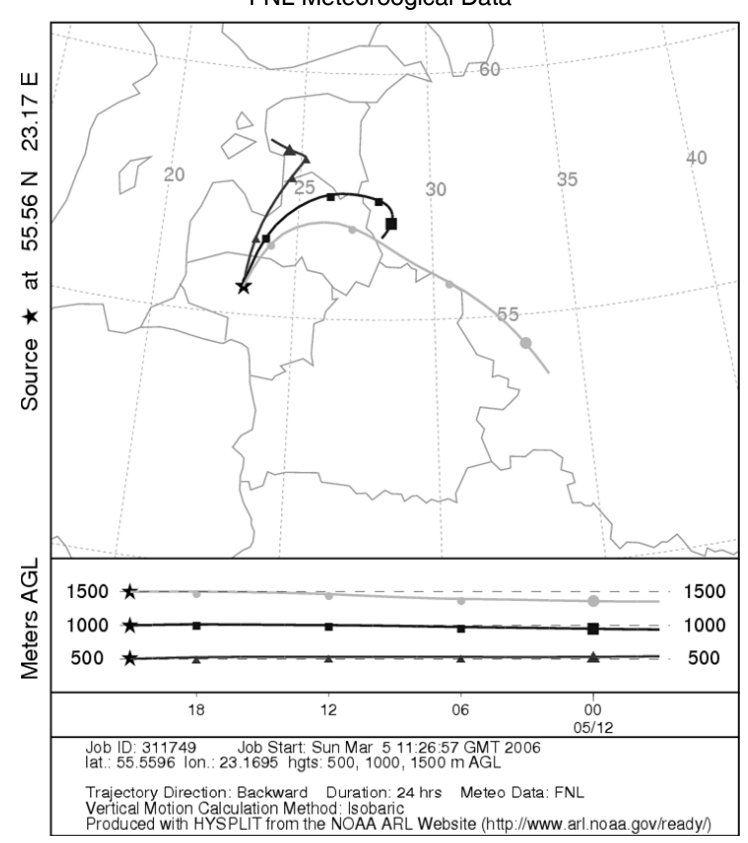

Fig 7. Backward trajectory analysis (24 hours) at three altitudes, start of run at 00:00, May 13, 2005

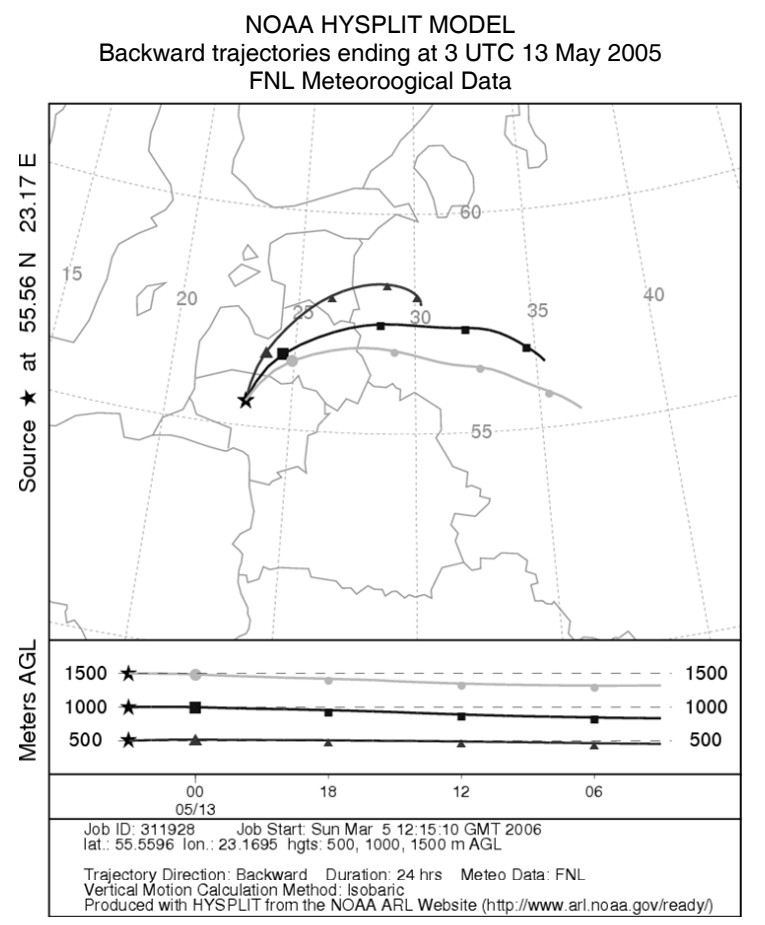

Fig 8. Backward trajectory analysis (24 hours) at three altitudes, start of run at 6:00, May 13, 2005

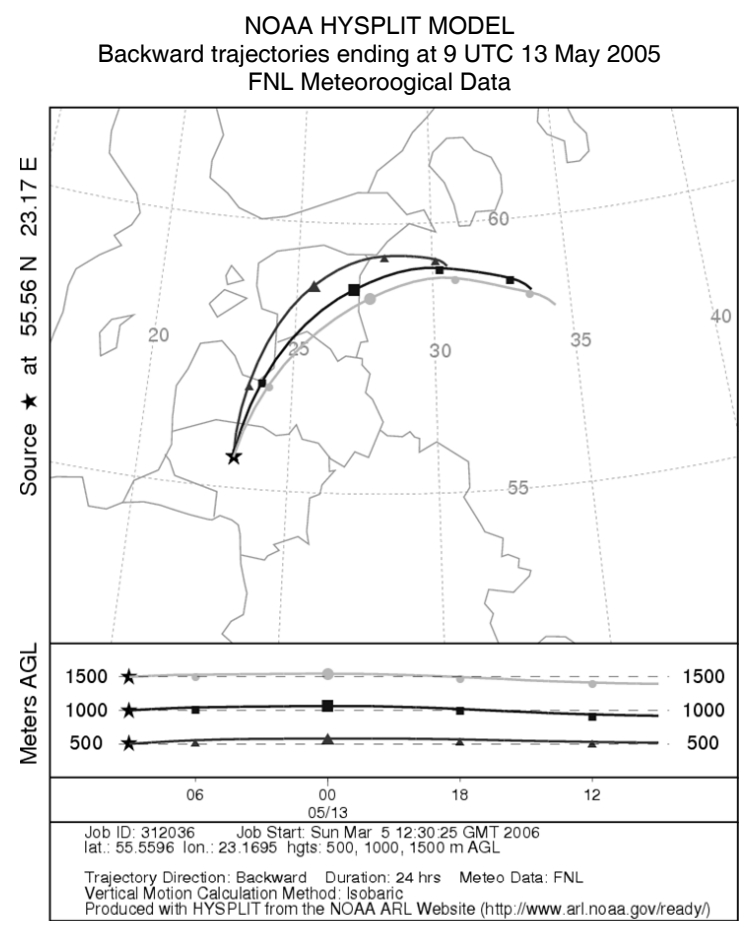

Fig 9. Backward trajectory analysis (24 hours) at three altitudes, start of run at 12:00, May 13, 2005

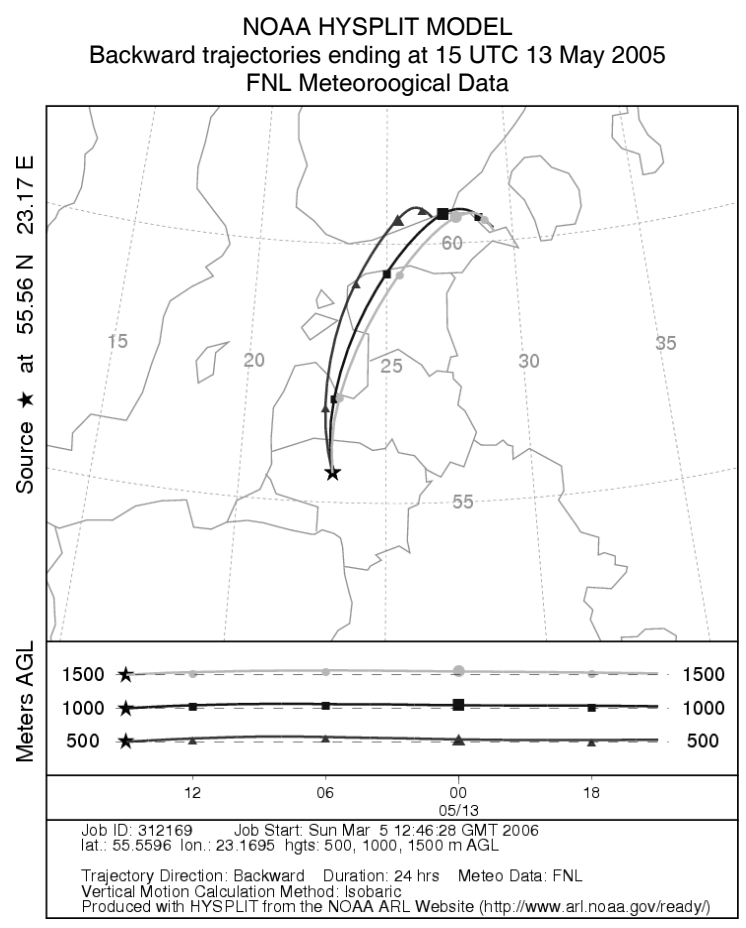

Fig 10. Backward trajectory analysis ( 24 hours) at three altitudes, start of run at 18:00, May 13, 2005 
Table 3. Meteorological data recorded on May 21, 2005

\begin{tabular}{c|c|c|c|c|c|c}
\hline Time & $\begin{array}{c}\text { Surface level } \\
\text { pressure } \\
\mathrm{mb}\end{array}$ & $\begin{array}{c}\text { Average } \\
\text { temperature, } \\
{ }^{\circ} \mathrm{C}\end{array}$ & $\begin{array}{c}\text { Minimal } \\
\text { temperature, } \\
{ }^{\circ} \mathrm{C}\end{array}$ & $\begin{array}{c}\text { Wind speed, } \\
\mathrm{m} / \mathrm{s}\end{array}$ & $\begin{array}{c}\text { Wind } \\
\text { direction, } \\
\text { degrees }\end{array}$ & $\begin{array}{c}\text { Relative } \\
\text { humidity, } \%\end{array}$ \\
\hline 24 & 1012,3 & 7 & 6,9 & 0 & Tyla & 73 \\
\hline 6 & 1011,1 & 3,5 & 3,2 & 0 & Tyla & 95 \\
\hline 12 & 1009,7 & 16,3 & 12,4 & 3 & 135 & 38 \\
\hline 18 & 1006,1 & 19,3 & 18,1 & 3 & 90 & 33 \\
\hline
\end{tabular}

air mass trajectories at a different height helped to explain why the increase of pollen concentration occurred at the end of pollination season.

The meteorological data of 24 hours (Table 3) were favourable for pollination: the day was sunny, a sudden change of relative humidity from $95 \%$ to $33 \%$, quite a high pressure. Evaluating the air mass that reached Šiauliai Aerobiological Station at a different time, the air mass movement of the same direction was stated: air mass moved from the southern part of Estonia through Russia, Latvia and northern Lithuania (Figs 11-12). On the way of the air mass there was no rainfall. According to the EAN data, in Latvia there was a large amount of birch pollen and it could get into the air mass moving towards Lithuania. A low morning temperature (Table 3) unfavourable for the pollination of local plants allows consideration of the probability of long-range transport, so it is possible to establish presumption that the birch pollen from southern Latvia could have been recorded at Śiauliai Aerobiological Station.

\section{Discussion}

This study has shown that backward trajectory analysis can be used to investigate specific pollen episodes.

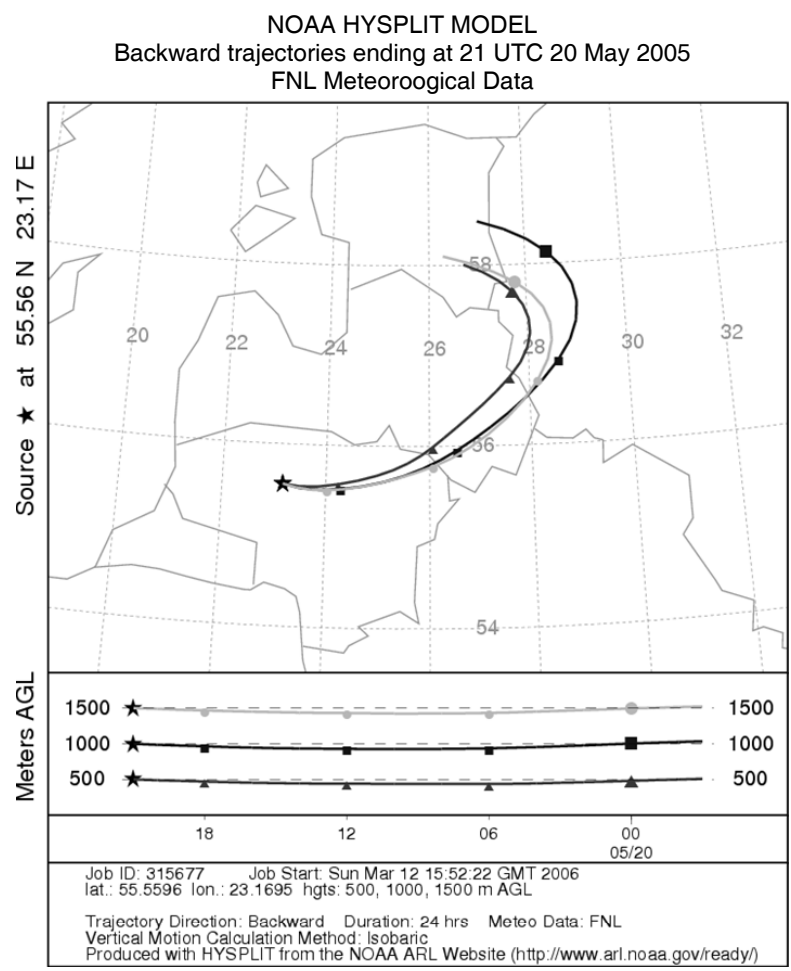

Fig 11. Backward trajectory analysis (24 hours) at three altitudes, start of run at 00:00, May 21, 2005

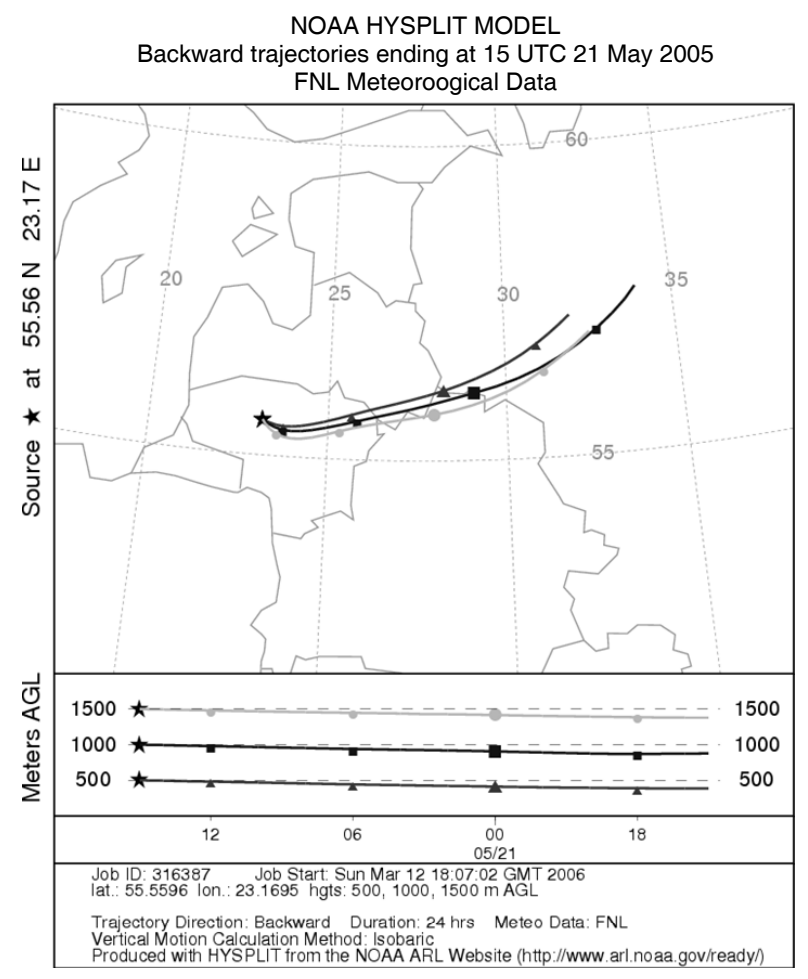

Fig 12. Backward trajectory analysis (24 hours) at three altitudes, start of run at 18:00, May 21, 2005

On May 3, 13, 21 the evaluation of the aerobiological situation was successful having used backward air mass trajectory analysis. Using the HYSPLIT 4 model, it is revealed why uncommonly large pollen concentrations were recorded. Possibility to use the EAN data allowed to establish presumption that under atypical conditions at Šiauliai Aerobiological Station the increase of pollen concentration may have been recorded not only because of the dynamics of the pollination of local flora, but also because of airborne pollen long-range transport.

Evaluating the importance of air mass movement for long-range pollen transport, it is necessary to choose a correct model. Application of the HYSPLIT 4 model revealed the regularities of transport and may be successfully used. Evaluation of pollen dispersion by the backward air mass trajectory method presented in the paper established the precondition to look for possibilities of application of the HYSPLIT 4 model to prepare the forecasts of pollen dispersion. Such a permanent control of pollen spread (together with evaluating the processes that determine long-range transport) is important for patients with allergic illnesses, patient associations, doctors, pharmaceutical companies, organizers of international sport and leisure events, tourism business. Precise pollen 
identification may decrease losses experienced because of mistakes in choosing medicine against a specific allergen that is usually of a nonlocal origin.

\section{Conclusions}

1. It is shown that backward air mass analysis may be applied in investigating relationship among pollen dispersion, meteorological conditions and air mass transport.

2. It is shown that the HYSPLIT 4 model may be used to investigate long-range pollen transport.

3. It is revealed that at Siauliai Aerobiological Station the dynamics of pollen concentration is conditioned by the local flora and airborne pollen long-range transport.

\section{References}

1. Filon, F. L.; Bosco, A.; Berbina, P.; Sauli, M. L.; Longo, L. R. Betulaceae and Corylaceae in Trieste (NEItaly): Aerobiological and clinical data. Aerobiologia, Vol 16, 2000, p. 87-91.

2. Corden, J.; Millington, W; Bailey, J.; Brookes, M.; Caulton, E.; Emberlin, J.; Mullins, J.; Simpson, C.; Wood, A. UK regional variations in Betula pollen (1993-1997). Aerobiologia, Vol 16, 2000, p. 227-232.

3. Radišić, P.; Šikoparija, B. Betula spp. Pollen in the atmosphere of Novi Sad (2000-2002). Aerobiologia, Vol 21, 2005, p. 63-67.

4. Mendez, J.; Comtois, P.; Iglesias, I. Betula pollen: One of the most important aeroallergens in Ourense, Spain. Aerobiological studies from 1993 to 2000. Aerobiologia, Vol 21, 2005, p. 115-123.
5. Latałowa, M.; Miętus, M.; Uruska, A. Seasonal variations in the atmospheric Betula pollen count in Gdańsk (southern Baltic coast) in relation to meteorological parameters. Aerobiologia, Vol 18, 2002, p. 33-43.

6. Laaidi, K. Predicting days of high allergenic risk during Betula pollination using weather types. International Journal of Biometeorology, Vol 45, 2001, p. 124-132.

7. Šaulienè, I.; Motiekaitytè, V. Pecularities of Aeropalinological Monitoring in Northern Lithuania. In: The 6th International Conference on Environmental Engineering. Selected Papers, Vol 1 (May 26-27 2005, Vilnius, Lithuania). Vilnius: Technika, 2005, p. 252-256.

8. Jager, S.; Spieksma, F. Th. M.; Nolard, N. Fluctuations and trends in airborne concentrations of some abundant pollen types, monitored at Vienna, Leiden, and Brussels. Grana, Vol 30, 1991, p. 3009-312.

9. Smith, M.; Emberlin, J.; Kress, A. Examing high magnitude grass pollen episodes at Worcester, United Kingdom, using back-trajectory analysis. Aerobiologia, Vol 21, 2005, p 85-94.

10. Kuliešis, A.; Kasperavičius, A.; Kulbokas, G.; Kvalkauskienè, M. Lietuvos nacionalinè miškų inventorizacija 1998-2002. Atrankos schema, metodai, rezultatai. Kaunas: Naujasis lankas, 2003. 256 p.

11. Mandrioli, P.; Comtois, P.; Levizzani, V. Methods in Aerobiology. Bologna: Pitagora Editrice, 1998. 262 p.

12. Draxler, R. R.; Rolph, G. D. HYSPLIT (HYbrid SingleParticle Lagrangian Integrated Trajectory) Model access via NOAA ARL READY Website (http://www.arl.noaa.gov/ready/hysplit4.html). NOAA Air Resources Laboratory, Silver Spring, MD, 2003.

\section{ŽIEDADULKIU DISPERSIJOS ATMOSFEROJE VERTINIMAS TAIKANT ATGALINIŲ ORO MASIŲ TRAJEKTORIJU ANALIZE}

\section{I. Šaulienè, L. Veriankaitė}

Santrauka

Žiedadulkių judèjimą atmosferoje aerobiologai tiria analizuodami atgalinių oro masių trajektorijas. Šiame straipsnyje gilinamasi į beržo žiedadulkių sklaidos atmosferoje ypatumus. Šiaulių aerobiologijos stotyje $2005 \mathrm{~m}$. žiedadulkès buvo fiksuojamos Hirst tipo sporų gaudykle. Žiedadulkių judèjimas žydint beržams aplinkinèse Europos šalyse buvo ịvertintas remiantis Europos aeroalergenų tinklo duomenų baze. Apibendrintais duomenimis pasinaudota, irodant tolimają žiedadulkių pernašą. Oro masių trajektorijos apskaičiuotos pagal HYSPLIT 4 modeli, trajektorijų brèžimo principą grindžiant oro masès padèties integravimu laiko atžvilgiu. Tyrimas parodè, kad atgalinių oro masių trajektorijų analizė gali būti taikoma tiriant sąsają tarp žiedadulkių dispersijos, meteorologinių sąlygų ir oro masių pernašos. Nustatyta, kad Šiaulių aerobiologijos stotyje žiedadulkių koncentracijos dinamiką lemia vietinè augalija ir žiedadulkių atmosferoje tolimosios pernašos. Straipsnyje pateiktas žiedadulkių dispersijos vertinimas atgalinių oro masių trajektorijų analizės metodu suformavo prielaidas siekti modelio HYSPLIT 4 taikymo galimybių žiedadulkių sklaidai prognozuoti.

Prasminiai žodžiai: žiedadulkès, meteorologinès sąlygos, tolimosios pernašos, atgalinès oro masių trajektorijos, beržo dulkejjimas, oro tarša.

\section{ОЦЕНКА ДИСПЕРСИИ ПЫЛЬЦЫ В АТМОСФЕРЕ ПО АНАЛИЗУ ТРАЕКТОРИЙ ОБРАТНЫХ ВОЗДУШНЫХ МАСС}

\section{И. Шаулене, Л. Верянкайте}

Р ез ю м е

Для исследования пыльцы в атмосфере аэробиологи используют траектории обратных атмосферных масс. В статье анализируются особенности рассеянности берёзовой пыльцы в атмосфере в 2005 г. Пыльца фиксировалась с использованием ловушки спор типа Хирст. Ситуация цветения берёзы в соседних странах Европы была оценена согласно данным базы Европейской сети по аэроаллергенам. Данные обобщены, использованы, доказан дальний 
перенос пыльцы. Траектории обратных воздушных масс установлены согласно модели HYSPLIT 4. Исследования показали, что анализ обратных воздушных масс может быть использован для изучения связи между дисперсией пыльцы, метеоусловиями и переносом атмосферных масс. Установлено, что на аэробиологической станции города Шяуляй динамика пыльцы предопределена местной флорой и дальними переносами. Представленная оценка дисперсии пыльцы может служить основой при изучении возможности использования HYSPLIT 4 для прогнозов.

Ключевые слова: пыльца, метеоусловия, дальний перенос, обратные траектории атмосферных масс, пыление берёзы, загрязнение воздуха.

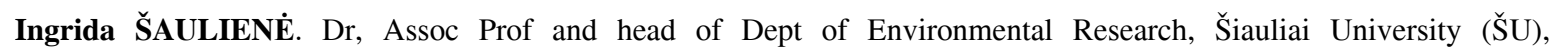
Vilniaus g. 88, LT-76285, Šiauliai, Lithuania.

Doctor of Natural Sciences (botany), 2002. Probation: Poznan University (Poland), Certificate of Aerobiologist, 2003; Institute of Zoology and Botany, Estonian Agricultural University, 2003; Faculty of Geography and Earth Sciences, University of Latvia, 2005. Membership: Lithuanian Association of Plant Physiology, Phenology Community of Lithuanian Association of Nature, International Association for Aerobiology, Nordic Aerobiology Federation. Publications: author of 11 research papers. Research interests: plant physiology (influence of environmental factors on plant regeneration processes), aerobiology, environment quality.

Laura VERIANKAITE். Master student, Dept of Hydrology and Climatology, Vilnius University (VU), M. K. Čiurlionio g. 21/27, LT-03101, Vilnius, Lithuania.

Bachelor of Ecology and Environmental Research, Šiauliai University. Research interests: meteorology, environmental research, aerobiology. 